\title{
PRE-EVALUASI GERAKAN ONE DAY NO RICE (ODNR) \\ DITINJAU DARI KEANEKARAGAMAN KONSUMSI PANGAN PEGAWAI DI KANTOR PEMERINTAH KOTA DEPOK
}

\author{
Pre-evaluation of "One Day No Rice (ODNR) Movement" \\ based on Food Diversification of Government Employee in Depok City
}

Trina Astuti, Dhea Christine

Politeknik Kesehatan Kemenkes Jakarta II, Jurusan Gizi

E-mail: trina_astuti@yahoo.com

\begin{abstract}
The aim of the study is to evaluate "One Day No Rice (ODNR) movement" based on food diversification consumption of government employee in Depok. The study design was descriptive analytic survey. Samples of 74 people were taken through purposive sampling. The inclusion criteria covered employee of Depok City Government, staffing level of II and III, worked at least 3 years, and healthy. Samples that have a history of diabetes mellitus were excluded.The results showed that of 68.9 per cent were aged less than 40 years; 58.1 per cent of men; 45.9 per cent had a degree of $S 1$ or equivalent; 66.2 per cent with staffing level of III. Amounted to 90.5 per cent employees informed about ODNR movement, but only 5.4 per cent have applied food diversification consumption. Fisher Exact test showed no relationship between application food diversification consumption among employees with age $(p=0.651)$, gender $(p=0.107)$, education level $(p=0.275)$, staffing level $(p=0,584)$ and knowledge on ODNR movement $(p=1.000)$. Considering the importance of food diversification, it is recommended to continue the movement with strengthened strategy on health promotion. Promotion with leaflets and brochures as well as nutrition balanced education associated with ODNR to prevent non-communicable diseases such as diabetes mellitus, obesity, and overweight caused by undiversified food consumption.
\end{abstract}

Keywords: ODNR, food diversification, food consumption

\section{ABSTRAK}

Tujuan studi adalah untuk mengevaluasi Gerakan One Day No Rice (ODNR) di Pemerintah Kota (Pemkot) Depok berdasarkan keanekaragaman konsumsi pangan pegawai. Desain penelitian adalah deskriptif analitis dengan pendekatan survei. Jumlah sampel 74 orang yang diambil secara purposif. Kriteria inklusi adalah pegawai Pemkot Depok dengan pangkat pegawai golongan II dan III, sudah bekerja minimal 3 tahun dan dalam keadaan sehat. Kriteria eksklusi adalah sampel yang mempunyai riwayat penyakit Diabetes Mellitus (DM). Hasil menunjukkan, sebesar 52,7 persen usia di bawah 40 tahun, 58,1 persen lakilaki, 45,9 persen pendidikan S1/sederajat dan 66,2 persen mempunyai kepangkatan golongan III. Sebesar 90,5 persen pegawai mengetahui Gerakan ODNR, namun hanya 5,4 persen pegawai dengan keanekaragaman konsumsi pangan sehari-hari. Uji Fisher Exact pada a 0,05 menunjukkan, tidak ada hubungan antara keanekaragaman konsumsi pangan pegawai dengan usia $(p=0,651)$, jenis kelamin $(p=$ $0,107)$, tingkat pendidikan $(p=0,275)$, golongan kepangkatan pegawai $(p=0,584)$ dan pengetahuan tentang Gerakan ODNR $(p=1,000)$. Saran agar Gerakan ODNR dilanjutkan dengan penguatan pada aspek promosi. Promosi Gizi Seimbang dilakukan melalui media leaflet dan brosur untuk mencegah penyakit tidak menular, seperti DM, kegemukan dan obesitas akibat konsumsi pangan yang tidak beragam.

Kata kunci: ONDR, keanekaragaman, konsumsi pangan

\section{PENDAHULUAN}

enganekaragaman pangan adalah upaya peningkatan ketersediaan dan konsumsi pangan yang beragam, bergizi seimbang, dan berbasis pada potensi sumber-daya lokal. Penganekaragam pangan disebut juga sebagai diversifikasi pangan. Program penganekaragaman pangan merupakan cara untuk meningkatkan pengembangan gizi yang 
lebih mencukupi pada tingkat daerah perdesaan, regional, dan nasional., ${ }^{1,2}$ Untuk mengurangi ketergantungan masyarakat pada pangan beras, pemerintah mengeluarkan Inpres No. 14 tahun 1974 tentang Penganekaragaman Menu Makanan Rakyat (PMMR) untuk mempengaruhi pola konsumsi masyarakat yang kemudian diperbarui dengan Inpres No. 20 tahun 1979 tentang Perbaikan Menu Makanan Masyarakat yang berdimensi permintaan terhadap keanekaragaman pangan. Dalam konteks ini, keanekaragaman konsumsi pangan dapat diartikan sebagai pengurangan konsumsi beras yang digantikan oleh penambahan konsumsi bahan pangan nonberas. ${ }^{3}$

Sampai saat ini, implementasi kebijakan Inpres 20/1979 belum berjalan lancar karena beberapa kesulitan. Misalnya, kesulitan mengubah cara atau kebiasaan makan masyarakat karena hal tersebut menyangkut aspek teknis (sulit-tidaknya bahan makanan tersebut dimasak), aspek sosial (menyangkut kebiasaan dan selera), dan aspek ekonomi (berkaitan dengan tingkat pendapatan dan harga bahan makanan). Widyakarya Nasional Pangan dan Gizi VII yang dilaksanakan pada bulan Februari 2000 mengidentifikasi 1,7 juta anak balita berada pada kondisi gizi buruk. Sehubungan dengan itu, diluncurkanlah Gerakan Nasional Penanggulangan Masalah Pangan dan Gizi dalam rangka mencapai cukup pangan dan bebas gizi buruk. Kebijakan perbaikan gizi ini juga melibatkan sektor lain, di antaranya sektor kesehatan dan pengembangan wilayah. ${ }^{3}$

Dikeluarkannya Perpres No. 22 tahun 2009 tentang kebijakan percepatan penganekaragaman konsumsi pangan berbasis sumber-daya lokal adalah karena penganekaragaman konsumsi pangan hingga kini belum mencapai kondisi yang optimal, yang dicirikan oleh skor Pola Pangan Harapan (PPH) yang belum sesuai harapan, dan belum optimalnya peran pangan lokal dalam mendukung penganekaragaman konsumsi pangan. ${ }^{4}$

Konsumsi beras dunia pada tahun 2009 sebesar $60 \mathrm{~kg} / \mathrm{kapita} / \mathrm{tahun}$. Di Indonesia, konsumsi beras nasional pada tahun 2009 mencapai $139,15 \mathrm{~kg} / \mathrm{kapita} / \mathrm{tahun}$. Sementara di Depok, konsumsi beras pada tahun 2009 mencapai $105 \mathrm{~kg} / \mathrm{kapita} /$ tahun. ${ }^{5}$ Sampai dengan tahun 2011, skor PPH nasional baru mencapai
77,3 , sedangkan Kota Depok dapat mencapai skor PPH sebesar 93,7 pada tahun 2011. Walaupun hal ini sudah baik, tetapi skor PPH Kota Depok masih di bawah skor PPH ideal, yakni sebesar 100.6,7 Masalah yang bisa didapatkan apabila pangan yang dikonsumsi tidak beragam adalah masyarakat berisiko diabetes, obesitas, dan overweight.

Prevalensi diabetes usia $\geq 15$ tahun di Indonesia sebesar 1,5 persen, sedangkan di Provinsi Jawa Barat sebesar 1,3 persen. Proporsi obesitas sentral pada penduduk umur $\geq 15$ tahun adalah 26,6 persen di Indonesia, sedangkan di Provinsi Jawa Barat 26,4 persen. Prevalensi status gizi overweight penduduk dewasa (>18 tahun) berdasarkan kategori IMT adalah 11,5 persen, sedangkan di Provinsi Jawa Barat 11,7 persen. Dilihat dari angka prevalensinya; diabetes, obesitas, dan overweight masih merupakan masalah yang harus ditanggulangi. 8,9

Pada tahun 2011, Walikota Depok menindaklanjuti Perpres 22/2009 dan Permentan 43/2009 tentang Gerakan Percepatan Penganekaragaman Konsumsi Pangan Berbasis Sumber-Daya Lokal dengan mengeluarkan Surat Edaran Walikota No. 500/1219-Ekonomi tanggal 23 September 2011 Depok tentang One Day No Rice (ODNR) setiap hari Senin dan direvisi dengan Surat Edaran Walikota Depok No. 500/1688-Ekonomi tanggal 27 Desember 2011 tentang ODNR setiap hari Selasa. ${ }^{10}$ Sasaran langsung dari surat edaran tersebut adalah seluruh pegawai di lingkungan Pemerintah Kota (Pemkot) Depok.

Tahap awal implementasi kebijakan ODNR, adalah menginstruksikan agar setiap hari Selasa, semua kantin di wilayah perkantoran Pemkot Depok tidak menyediakan makanan berbahan utama beras dan terigu. Setiap hari Selasa, seluruh pegawai negeri sipil Pemkot Depok diimbau untuk tidak makan makanan berbahan utama beras dan terigu. Setelah setahun ODNR diberlakukan, konsumsi beras pun menurun 3,79 persen, melebihi target nasional 1,5 persen, dari $264 \mathrm{~g}$ per orang/hari pada 2011 menjadi $254 \mathrm{~g}$ per orang/hari pada 2012.10 Indikator keberhasilan peningkatan penganekaragaman pangan dapat dilihat dari persentase penurunan konsumsi beras, meningkatnya konsumsi umbi-umbian, pangan hewani, sayuran dan buah-buahan serta meningkatnya skor PPH. Skor PPH dapat 
merepresentasikan jumlah kalori yang dikonsumsi dari berbagai variasi makanan..$^{10}$

Studi Rosmauli (2013) mempublikasikan deskripsi dalam hal implementasi Gerakan ODNR dan belum dilakukan evaluasi pada tingkat individu. ${ }^{11}$ Studi ini bertujuan mengevaluasi Gerakan ODNR dalam meningkatkan Keanekaragaman Konsumsi Pangan Pegawai di Kantor Pemkot Depok.

\section{METODE PENELITIAN}

Penelitian ini dilakukan di Kantor Pemkot Depok. Desain penelitian adalah deskriptif analitis dengan pendekatan survei. Populasi adalah pegawai Pemkot Depok yang merupakan sasaran langsung Surat Edaran Walikota No. 500/1688 tanggal 27 Desember 2011 tentang ODNR. Sampel adalah pegawai Pemkot Depok yang sudah bekerja minimal 3 tahun, golongan kepegawaian II dan III, bersedia menjadi responden, dan dalam keadaan sehat. Kriteria eksklusi adalah sampel dengan riwayat diabetes mellitus (DM). Besar sampel dihitung menggunakan estimasi proporsi dengan estimasi mutlak. Cara pengambilan sampel dilakukan secara purposif. Data primer, seperti karakteristik pegawai dan tingkat pengetahuan tentang Gerakan ODNR, dikumpulkan melalui wawancara langsung dengan alat bantu kuesioner. Sementara keanekaragaman konsumsi pangan pegawai di Kantor Pemkot Depok diperoleh dengan metode Food Recall 24 Hour selama 2 hari tidak berturut-turut, yang dilakukan pada hari Rabu dan Jumat. Data sekunder mencakup media sosialisasi, sasaran sosialisasi, dan bentuk kegiatan sosialisasi ODNR diperoleh dari laporan tahunan. Data konsumsi pangan diolah dengan Food Processor dan dibandingkan dengan Angka Kecukupan Energi (AKE), sedangkan keanekaragaman konsumsi pangan dihitung berdasarkan skor PPH. Data pengetahuan dikategorikan menjadi "tahu" bila skor $\geq 5$ dan "tidak tahu" bila skor $\leq 4$.

Tabel 1

Karakteristik Pegawai Pemerintah Kota Depok

\begin{tabular}{lcc}
\hline Karakteristik & $\mathrm{n}$ & $\%$ \\
\hline Usia: & & \\
$-\quad$ <30 tahun & 9 & 12,2 \\
$-\quad 30-39$ tahun & 30 & 40,5 \\
$-\quad 40-49$ tahun & 25 & 33,8 \\
- $\geq 50$ tahun & 10 & 13,5 \\
Jenis kelamin: & & \\
- Laki-laki & 43 & 58,1 \\
- Perempuan & 31 & 41,9 \\
Tingkat pendidikan: & & \\
- SMA/sederajat & 7 & 9,5 \\
- D3/sederajat & 13 & 17,6 \\
- S1/sederajat & 34 & 45,9 \\
- S2/sederajat & 20 & 27,0 \\
Golongan kepegawaian: & & \\
- Gol II & 25 & 33,8 \\
- Gol III & 49 & 66,2 \\
Unit/Bidang kerja: & & \\
- Badan Kepegawaian Daerah (BKD) & 26 & 35,1 \\
- Badan Lingkungan Hidup (BLH) & 26 & 35,1 \\
- Dinas Perindustrian dan Perdagangan & 21 & 28,4 \\
- Dinas Pendidikan & 1 & 1,4 \\
\hline
\end{tabular}


HASIL

\section{Karakteristik}

Sebagian besar pegawai berusia 25-42 tahun dengan usia terendah 25 tahun dan tertinggi 59 tahun. Hasil ini berbeda dengan data BPS yang menyatakan proporsi terbesar $(56,1 \%)$ pada kelompok usia 43-59 tahun. Sebagian besar berjenis kelamin perempuan, dengan tingkat pendidikan S1/sederajat, serta memiliki pangkat dan golongan kepegawaian III. Secara rinci dapat dilihat pada Tabel 1.

\section{Sosialisasi Gerakan One Day No Rice (ODNR)}

Sosialisasi Gerakan ODNR terdiri dari penyebaran surat edaran, surat imbauan, dan surat instruksi; kampanye; dan seminar. Sosialisasi ODNR menggunakan media berupa banner, spanduk, poster, slide presentasi, dan surat. Sasaran dari sosialisasi ODNR adalah pegawai Kantor Pemkot Depok, kantin dan warung makan sekitar wilayah Kantor Pemkot
Depok, ibu-ibu PKK, dan masyarakat Kota Depok. Secara rinci dapat dilihat pada Tabel 2.

\section{Tingkat pengetahuan pegawai tentang Gerakan ODNR}

Sebagian besar pegawai $(90,5 \%)$ di Kantor Pemkot Depok mengetahui tentang arti ODNR, telah menjawab "Ya" 5-8 pertanyaan yang diajukan seputar ODNR. Angka ini lebih rendah dari harapan, yaitu seharusnya 100 persen pegawai tahu setelah dikeluarkan dan diberlakukannya Gerakan ODNR di Kantor Pemkot Depok. Kenyataannya masih 9,5 persen yang tidak tahu tentang Gerakan ODNR. Secara rinci dapat dilihat pada Tabel 3.

Hal-hal yang kurang diketahui oleh pegawai terkait dengan Gerakan ODNR adalah pelaksanaan ODNR yang dilakukan setiap hari Selasa berjalan efektif, diikuti informasi dari berbagai media massa, kebijakan dan tujuan ODNR, serta arti mendukung gerakan ODNR, yang secara rinci dapat dilihat pada Tabel 4 .

Tabel 2

Sosialisasi Gerakan ODNR di Kantor Pemerintah Kota Depok

\begin{tabular}{lll}
\hline Bentuk Sosialisasi & Media yang Digunakan & Sasaran \\
\hline $\begin{array}{l}\text { Penyebaran surat } \\
\text { edaran, surat } \\
\text { imbauan, dan surat } \\
\text { instruksi }\end{array}$ & $\begin{array}{l}\text { Surat dari Walikota Depok } \\
\text { secara langsung }\end{array}$ & Kepala OPD se-Kota Depok \\
Kampanye & $\begin{array}{l}\text { Banner, spanduk, dan } \\
\text { poster }\end{array}$ & $\begin{array}{l}\text { Pegawai di Kantor Pemkot } \\
\text { Depok, ibu PKK, dan } \\
\text { masyarakat Kota Depok }\end{array}$ \\
& $\begin{array}{l}\text { Slide presentasi dan } \\
\text { spanduk }\end{array}$ & $\begin{array}{l}\text { Kantin, restoran, hotel, wisma, } \\
\text { pusdiklat di Kota Depok. }\end{array}$ \\
\hline
\end{tabular}

Tabel 3

Distribusi Tingkat Pengetahuan Pegawai tentang Gerakan ODNR di Kantor Pemerintah Kota Depok

\begin{tabular}{lcc}
\hline Tingkat Pengetahuan & $\mathrm{n}$ & $\%$ \\
\hline Mengetahui & 67 & 90,5 \\
Kurang mengetahui & 7 & 9,5 \\
\hline Total & 74 & 100,0 \\
\hline
\end{tabular}


Tabel 4

Distribusi Pengetahuan Tiap Aspek Gerakan ODNR di Kantor Pemerintah Kota Depok

\begin{tabular}{|c|c|c|c|c|}
\hline \multirow{2}{*}{ Aspek } & \multicolumn{2}{|c|}{ Mengetahui } & \multicolumn{2}{|c|}{ Kurang Mengetahu } \\
\hline & $\mathrm{n}$ & $\%$ & $\mathrm{n}$ & $\%$ \\
\hline $\begin{array}{l}\text { Yang dimaksud dengan ODNR adalah } \\
\text { sehari tanpa nasi }\end{array}$ & 68 & 91,9 & 6 & 8,1 \\
\hline $\begin{array}{l}\text { Informasi tentang ODNR dari berbagai } \\
\text { media massa }\end{array}$ & 58 & 78,4 & 16 & 21,6 \\
\hline $\begin{array}{l}\text { Yang mengeluarkan kebijakan ODNR } \\
\text { adalah Walikota Depok }\end{array}$ & 73 & 98,6 & 1 & 1,4 \\
\hline $\begin{array}{l}\text { Kebijakan ODNR dilaksanakan setiap hari } \\
\text { Selasa }\end{array}$ & 73 & 98,6 & 1 & 1,4 \\
\hline $\begin{array}{l}\text { Kebijakan ODNR yang dilaksanakan setiap } \\
\text { hari Selasa berjalan efektif }\end{array}$ & 14 & 18,9 & 60 & 81,1 \\
\hline Memahami tentang kebijakan ODNR & 62 & 83,8 & 12 & 16,2 \\
\hline Mendukung Gerakan ODNR & 63 & 85,1 & 11 & 14,9 \\
\hline Tujuan Gerakan ODNR & 62 & 83,8 & 12 & 16,2 \\
\hline
\end{tabular}

Tabel 5

Distribusi Keanekaragaman Konsumsi Pangan Pegawai di Kantor Pemerintah Kota Depok

\begin{tabular}{lcc}
\hline Keanekaragaman Konsumsi Pangan Pegawai & $\mathrm{n}$ & $\%$ \\
\hline Kurang beragam (skor PPH <95) & 4 & 5,4 \\
Beragam (skor PPH $\geq 95$ ) & 70 & 94,6 \\
\hline Total & 74 & 100,0 \\
\hline
\end{tabular}

Tabel 6

Proporsi Konsumsi Pangan Yang Kurang Beragam Berdasarkan Kelompok Pangan pada Pegawai Kantor Pemerintah Kota Depok

\begin{tabular}{lccccc}
\hline \multirow{2}{*}{ Kelompok Pangan } & \multicolumn{2}{c}{ Kurang Beragam } & & \multicolumn{2}{c}{ Beragam } \\
\cline { 2 - 3 } \cline { 5 - 6 } & $\mathrm{n}$ & $\%$ & & $\mathrm{n}$ & $\%$ \\
\hline Padi-padian & 44 & 59,0 & & 30 & 41,0 \\
Umbi-umbian & 54 & 73,0 & & 20 & 27.0 \\
Pangan Hewani & 27 & 36,0 & & 47 & 64,0 \\
Minyak dan Lemak & 55 & 74,0 & & 19 & 26,0 \\
Buah/Biji berminyak & 40 & 54,0 & & 34 & 46,0 \\
Kacang-kacangan & 50 & 68,0 & & 24 & 32,0 \\
Gula & 52 & 70,0 & & 22 & 30,0 \\
Sayur dan Buah & 56 & 76,0 & & 18 & 24,0 \\
\hline
\end{tabular}

Tabel 4 menunjukkan bahwa sebesar 81,1 persen pegawai kurang mengetahui tentang kebijakan ODNR yang dilaksanakan setiap hari Selasa berjalan efektif dan 21,6 persen pegawai kurang mengetahui informasi tentang ODNR dari berbagai media massa. Pegawai yang kurang mengetahui informasi tentang ODNR dari berbagai media massa menyebutkan bahwa mereka jarang menggunakan media massa, seperti koran dan majalah, serta 
pegawai tidak pernah mendapatkan informasi ODNR, baik dari televisi maupun radio.

\section{Keanekaragaman konsumsi pangan pegawai}

Keanekaragaman konsumsi pangan pegawai diukur dengan hasil perhitungan skor $\mathrm{PPH}$. Rerata skor PPH pegawai di Kantor Pemkot Depok adalah 65,06 \pm 15,45 terendah 31,97 dan tertinggi 98,08 . Skor PPH ini masih berada di bawah sasaran percepatan penganekaragaman konsumsi pangan berbasis sumber-daya lokal, yakni skor PPH sebesar 95 pada tahun 2015. Skor PPH ini juga masih berada di bawah capaian skor PPH secara nasional tahun 2015 , yaitu 85,2 dan masih di bawah skor PPH Kota Depok tahun 2011, yakni 93,7. Merujuk pada skor PPH tahun 2015 sesuai sasaran percepatan penganekaragaman konsumsi pangan berbasis sumber-daya lokal, yaitu sebesar 95. Hasil studi ini dikelompokkan menjadi 2 kategori, yaitu kurang beragam bila konsumsi pangan pegawai memiliki skor PPH $<95$ dan kategori beragam bila konsumsi pangan pegawai memiliki skor $\mathrm{PPH} \geq 95$, seperti pada Tabel 5.

Tabel 5 menunjukkan bahwa sebagian besar konsumsi pangan sehari-hari pegawai Pemkot Depok masih kurang beragam $(94,5 \%)$. Artinya, konsumsi pangan pegawai di Kantor
Pemkot Depok belum beraneka ragam dan belum sesuai dengan gizi seimbang. Hal ini akan berdampak pada risiko masalah kesehatan berupa DM, obesitas, dan overweight. Hanya sebagian kecil (5,4\%) pegawai di Kantor Pemkot Depok yang mencapai atau melebihi skor PPH 95, yang artinya konsumsi pangan sudah beragam dan mencapai sasaran percepatan penganekaragaman konsumsi pangan berbasis sumber-daya lokal tahun 2015.

\section{Kelompok pangan yang kurang beragam}

Tabel 6 menunjukkan bahwa proporsi terbesar kelompok pangan yang beragam adalah pada pangan hewani $(64,0 \%)$. Konsumsi kelompok pangan lainnya lebih banyak yang kurang beragam. Sebesar 76,0 persen pegawai mengonsumsi sayur dan buah yang kurang beragam. Konsumsi umbi-umbian dan padipadian pada pegawai yang kurang beragam masing-masing mencapai 73 persen dan 59 persen. Ini bisa berarti, Gerakan ODNR belum sepenuhnya diimplementasikan ke dalam kehidupan sehari-hari. Konsumsi pegawai masih tergantung pada padi-padian dan satu jenis umbi-umbian tertentu sebagai sumber energi.

Tabel 7

Distribusi Keanekaragaman Konsumsi Pangan berdasarkan Karakteristik Pegawai di Kantor Pemerintah Kota Depok

\begin{tabular}{|c|c|c|c|c|c|}
\hline \multirow[b]{2}{*}{ Karakteristik } & \multicolumn{2}{|c|}{ Kurang beragam } & \multicolumn{2}{|c|}{ Beragam } & \multirow[t]{2}{*}{$\mathrm{p}$} \\
\hline & $\mathrm{n}$ & $\%$ & $\mathrm{n}$ & $\%$ & \\
\hline \multicolumn{6}{|l|}{ Kelompok usia: } \\
\hline$-<40$ tahun & 37 & 94,9 & 2 & 5,1 & 0.651 \\
\hline$-\quad \geq 40$ tahun & 33 & 94.3 & 2 & 5,7 & \\
\hline \multicolumn{6}{|l|}{ Jenis kelamin: } \\
\hline - Laki-laki & 31 & 100,0 & 0 & 0,0 & 0,107 \\
\hline - Perempuan & 39 & 90,7 & 4 & 9,3 & \\
\hline \multicolumn{6}{|l|}{ Tingkat pendidikan: } \\
\hline - $<$ S1/sederajat & 20 & 100,0 & 0 & 0,0 & 0,275 \\
\hline - $\geq S 1 /$ sederajat & 50 & 92,6 & 4 & 7,4 & \\
\hline \multicolumn{6}{|l|}{ Golongan kepangkatan: } \\
\hline - Gol II (dua) & 24 & 96,0 & 1 & 4,0 & 0,584 \\
\hline - Gol III (tiga) & 46 & 93,9 & 3 & 6,1 & \\
\hline Total & 70 & 94,6 & 4 & 5,4 & \\
\hline
\end{tabular}


Tabel 8

Distribusi Keanekaragaman Konsumsi Pangan berdasarkan

Pengetahuan Pegawai tentang Gerakan ODNR

\begin{tabular}{lccccc}
\hline \multirow{2}{*}{ Pengetahuan } & \multicolumn{3}{c}{ Keanekaragaman Konsumsi Pangan } \\
\cline { 2 - 3 } \cline { 2 - 3 } \cline { 5 - 6 } & \multicolumn{2}{c}{ Kurang Beragam } & & \multicolumn{3}{c}{ Beragam } \\
\cline { 2 - 3 } Kurang mengetahui & 7 & 100,0 & & 0 & 0,0 \\
Mengetahui & 63 & 94,0 & & 4 & 6,0 \\
\hline Total & 70 & 94,6 & & 4 & 5,4 \\
\hline
\end{tabular}

\section{Keanekaragaman konsumsi pangan berdasarkan karakteristik pegawai}

Konsumsi pangan pegawai Pemkot Depok dengan kategori kurang beragam, proporsinya lebih besar pada pegawai kelompok usia 25-42 tahun, jenis kelamin laki-laki, tingkat pendidikan di bawah strata satu atau sederajat dan dengan pangkat kepegawaian golongan II. Uji statistik dengan Fisher Exact pada $\mathrm{a}=0,05$ menunjukkan, tidak terdapat hubungan antara keanekaragaman konsumsi pangan dengan karakteristik pegawai. Secara rinci dapat dilihat pada Tabel 7.

\section{Keanekaragaman konsumsi pangan berdasarkan pengetahuan ODNR}

Pegawai dengan konsumsi pangan beragam, proporsi terbesar ada pada pegawai yang mengetahui Gerakan ODNR (6,0\%), sedangkan pegawai dengan konsumsi pangan kurang beragam, proporsi terbesar pada pegawai yang kurang mengetahui tentang Gerakan ODNR (100\%). Namun, uji Fisher Exact menunjukkan, tidak terdapat hubungan antara keanekaragaman konsumsi pangan dengan pengetahuan pegawai tentang Gerakan ODNR $(p=1,000)$. Data secara lengkap dapat dilihat pada Tabel 8.

\section{BAHASAN}

Gerakan ODNR ini merupakan implementasi dari Inpres No. 14 tahun 1974 yang diperbarui menjadi Inpres No. 20 tahun 1979 tentang Perbaikan Menu Makanan Rakyat. Penganekaragaman jenis pangan yang dikonsumsi penduduk mencakup pangan sumber energi (makanan pokok) dan zat gizi, yang bertujuan untuk memenuhi kebutuhan gizi seimbang, baik kuantitas maupun kualitas.
Gerakan ODNR di Kota Depok dilaksanakan sejak tahun 2012 berdasarkan Surat Edaran Walikota No. 500/1688-Ekonomi tanggal 27 Desember 2011.12 ODNR tidak melarang pegawai Pemkot Depok makan nasi. Namun, lebih pada gerakan membangun kembali dan menyempurnakan budaya makan aneka ragam pangan lokal menuju Indonesia sehat dan sejahtera. Kebijakan ODNR ini dilaksanakan secara efektif setiap hari Selasa, yang didukung juga oleh Badan Ketahanan Pangan Nasional dalam kampanye sehari tanpa nasi. Kebijakan ini diharapkan dapat menghemat beras sebanyak 22 ton/tahun, ${ }^{13}$ mengingat bahwa rerata keluarga di Indonesia mengonsumsi beras, jagung dan gandum $316 \mathrm{~g}$ per kapita/hari yang lebih besar dari konsumsi ideal, yakni 275 $\mathrm{g}$ per kapita/hari. Sementara itu, konsumsi umbi-umbian hanya $40 \mathrm{~g}$ per hari, yang jauh lebih rendah dari yang seharusnya, yaitu $100 \mathrm{~g}$ per hari. ${ }^{14}$ Kebijakan ODNR yang sudah berjalan selama 4 tahun berhasil meningkatkan pengetahuan pegawai $(90,5 \%)$ tentang gerakan tersebut. Namun, masih belum menerapkan dalam konsumsi sehari-hari. Berbeda dengan studi Sari (2014) yang menyatakan bahwa ada hubungan yang kuat antara Pesan Kampanye ODNR dan Sikap Pegawai Aparatur Pemkot Depok terhadap Pola Konsumsi Beras. ${ }^{15}$

Keanekaragaman konsumsi pangan sehari pada pegawai adalah keadaan susunan keragaman konsumsi pangan pegawai di Kantor Pemkot Depok yang didapatkan dari rerata hasil Food Recall 24 Hours selama dua hari tidak berturut-turut, yang diolah menggunakan Food Processor. Kemudian dilakukan perhitungan skor PPH. Hasil studi menunjukkan, sebagian besar pegawai mempunyai konsumsi pangan yang kurang beragam pada konsumsi sayur dan buah $(76 \%)$, konsumsi minyak dan lemak 
(74\%), konsumsi umbi-umbian (73\%), dan kacang-kacangan $(68 \%)$. Kualitas pangan pegawai Pemkot Depok, yang ditunjukkan dengan rerata skor PPH, baru mencapai 65,06 $\pm 15,45$ (terendah 31,97 dan tertinggi 98,08) yang masih jauh di bawah skor normatif Kota Depok, yakni 93,7 dan skor ideal, yaitu 100. Namun, skor PPH hasil studi ODNR di Pemkot Depok ini masih lebih baik dibandingkan dengan skor PPH penduduk Indonesia usia dewasa $(53,1 \pm 9,3)$, rumah-tangga perdesaan di Kabupaten Malang $(52,23)$ dan penduduk desa di Kabupaten Jombang $(52,82)$. 16,17,18 Sebaliknya, skor PPH pegawai Pemkot Depok lebih rendah dibandingkan dengan skor PPH masyarakat Indonesia pada tahun $2009^{19}$ dan skor PPH rumah-tangga perkotaan di Tarakan Kalimantan Timur. ${ }^{20}$

Terkait dengan keberhasilan Gerakan ODNR yang lebih fokus pada pengakeragaman konsumsi sumber karbohidrat, sebagian besar (73\%) pegawai Pemkot Depok masih sedikit yang mengonsumsi umbi-umbian yang ditunjukkan dari skor PPH umbi-umbian, yaitu baru mencapai 0,98 , yang berada jauh di bawah skor ideal, yakni 2,5. Artinya, pegawai di Kantor Pemkot Depok lebih banyak mengonsumsi jenis pangan berupa padi-padian dibandingkan dengan umbi-umbian. Selain belum beragamnya konsumsi pangan pegawai, juga belum sesuai dengan konsep Gizi Seimbang. Hal ini belum sejalan dengan tujuan diadakannya ODNR, yakni menurunnya konsumsi beras dan meningkatnya konsumsi umbi-umbian, pangan hewani, sayuran dan buah-buahan.

Evaluasi yang dilakukan Ismail (2015) menunjukkan bahwa sosialisasi gerakan dan implementasi ODNR telah dilakukan dalam bentuk rapat dan pertemuan hari Selasa dengan kantin Pemkot Depok, anak sekolah dan guru-guru, pelayanan diet menu pasien di RS Kota Depok dan masyarakat umum. ${ }^{21}$ Tahun 2013, bahkan, telah diluncurkan batik ODNR yang bermotif berbagai varian karbohidrat yang dapat dikonsumsi sebagai pengganti nasi. ${ }^{22}$ Namun, kenyataannya, masih banyak $(94,5 \%)$ pegawai dengan konsumsi pangan yang kurang beragam ,yang dapat berdampak pada masalah kesehatan berupa diabetes mellitus, obesitas, dan overweight.
Gerakan ODNR yang sudah berjalan selama 4 tahun (tahun 2012 - Februari 2016) belum mencapai hasil yang diharapkan, baik dari segi pemahaman pegawai tentang ODNR maupun implementasinya. Kendala yang dihadapi pegawai terkait kurangnya pengetahuan tentang gerakan One Day No Rice, adalah pemahaman yang belum utuh tentang kebijakan One Day No Ricesehingga belum berjalan efektif. Berdasarkan wawancara dengan sampel pegawai bahwa, masih banyak pegawai yang tetap mengonsumsi beras di hari Selasa dan mengikuti kegiatan One Day No Rice di kantor dengan berpuasa.

Kelemahan dalam gerakan ini adalah tidak ada lembaga bertanggung jawab dalam monitoring gerakan ODNR sehingga tidak dapat dilakukan evaluasi secara periodik. Masalah yang mungkin timbul adalah semakin meningkatnya permintaan konsumsi beras seiring diberhentikannya kebijakan Gerakan ODNR sejak Februari 2016. Padahal diversifikasi konsumsi pangan sangat berperan dalam kaitannya dengan aspek gizi, kesehatan dan kualitas SDM, baik menyangkut pertumbuhan fisik, perkembangan mental, kecerdasan maupun produktivitas kerja. Maka, perlu peninjauan kembali untuk mengaktifkan Gerakan ODNR.

\section{SIMPULAN DAN SARAN}

\section{Simpulan}

Sebagian besar pegawai di Kantor Pemkot Depok telah mengetahui tentang gerakan ODNR. Sosialisasi Gerakan ODNR berupa penyebaran surat; kampanye; dan seminar menggunakan media berupa banner, spanduk, poster, slide presentasi, dan surat dengan sasaran pegawai Kantor Pemkot depok, kantin dan warung makan sekitar wilayah Kantor Pemkot Depok, ibu-ibu PKK, dan masyarakat Kota Depok. Namun, konsumsi pangan sebagian besar pegawai kurang beragam, dengan proporsi terbanyak pada pegawai dengan usia di bawah 40 tahun, jenis kelamin laki-laki, tingkat pendidikan S1/sederajat ke bawah, bergolongan kepegawaian II (dua), dan kurang mengetahui tentang Gerakan ODNR. Penelitian ini tidak menunjukkan adanya hubungan antara keanekaragaman konsumsi pangan dengan usia, jenis kelamin, tingkat 
pendidikan, golongan kepegawaian, dan tingkat pengetahuan tentang ODNR.

\section{Saran}

Diversifikasi konsumsi pangan sangat berperan dalam kaitannya dengan aspek gizi, kesehatan dan kualitas SDM, baik menyangkut pertumbuhan fisik, perkembangan mental, kecerdasan maupun produktivitas kerja. Perlu peninjauan kembali untuk mengaktifkan Gerakan ODNR, yang diperkuat dengan kegiatan promosi yang lebih efektif. Promosi tentang keanekaragaman konsumsi pangan dan konsep Gizi Seimbang terkait dengan ODNR melalui leaflet, poster dan seminar penting untuk mencegah timbulnya penyakit tidak menular, seperti DM, obesitas, dan overweight.

\section{UCAPAN TERIMA KASIH}

Terima kasih kami sampaikan kepada Pemkot Depok yang telah memberi ijin untuk pelaksanaan dan kelancaran penelitian ODNR. Ucapan terima kasih juga kami sampaikan kepada Bapak dan Ibu pegawai di lingkungan Pemkot Depok atas kesediaan berpartisipasi aktif sebagai subyek penelitian, serta pihakpihak lain yang telah membantu kelancaran penelitian.

\section{RUJUKAN}

1. Indonesia, Dewan Perwakilan Rakyat. Undang-Undang Nomor 18 tentang Pangan. Jakarta: DPR RI, 2012

2. Harper LJ. Pangan, Gizi dan Pertanian. Jakarta: UI Press, 2009.

3. Hanafie R. Pengantar Ekonomi Pertanian. Yogyakarta: Andi Offset, 2010.

4. Indonesia, Presiden. Peraturan Presiden Republik Indonesia Nomor 22 tentang Kebijakan Percepatan Penganekaragaman Konsumsi Pangan Berbasis Sumber-Daya Lokal. Jakarta: Presiden RI, 2009.

5. Indonesia, Departemen Pertanian. Konsumsi Beras Penduduk Asia per Kapita. Jakarta: Deptan RI, 2009.

6. Indonesia, Departemen Pertanian. Pola Pangan Harapan Kota Depok. Depok: Deptan RI, 2011.
7. Indonesia, Departemen Pertanian. Pola Pangan Harapan Nasional. Jakarta: Deptan Rl, 2011.

8. Pemerintah Kota Depok, Dinas Komunikasi dan Informasi. ODNR: Gerakan Revolusi Mindset. Depok: Pemkot Depok, 2013.

9. Indonesia, Badan Penelitian dan Pengembangan Kesehatan (Balitbangkes) Kementerian Kesehatan. Pokok-pokok Hasil Riset Kesehatan Dasar (Riskesdas) Indonesia 2013. Jakarta: Badan Litbangkes, 2013.

10. Ismail NM. One Day No Rice: Gerakan Lokal untuk Indonesia. Jakarta: Gramedia Pustaka Utama, 2012.

11. Rosmauli R. Implementasi Program One Day No Rice di Kota Depok. Jakarta: Universitas Indonesia, 2013.

12. Pemerintah Kota Depok. Surat Edaran Walikota Nomor 500/1688-Ekonomi, tanggal 27 Desember $2011 \quad$ tentang Ketahanan Pangan One Day No Rice Setiap Hari Selasa. Depok: Pemkot Depok, 2011.

13. Virdhani MH. Atasi Kemiskinan, BKPN Dukung ODNR. Okezone.com Jum'at 20 Oktober 2013. Diunduh tanggal 4 September 2016.

14. LKBN Antara. ODNR to become national program. Jakarta Globe 9 Juni 2012. Diunduh tanggal 4 September 2016.

15. Sari K. Studi korelasi mengenai hubungan pesan kampanye One Day No Rice dan sikap pegawai aparatur pemerintahan Kota Depok terhadap pola konsumsi beras. Bandung: Sub-Program Studi Hubungan Masyarakat, Fakultas IImu Komunikasi Universitas Padjadjaran, 2014.

https://pustaka.unpad.ac.id/archives/12370 1. Diunduh tanggal 4 September 2016.

16. Anwar K, Hardinsyah. Konsumsi pangan dan gizi serta skor PPH pada penduduk usia 19-49 tahun. JGP 2014, 9(1):51-58.

17. Y, Gima Iftitah Anugerah. 2015. Diversifikasi konsumsi pangan rumah tangga pedesaan di desa Sukolilo Kecamatan Wajak Kabupaten Malang. Jurnal Gema. 2015:1-22. http://jurnal.unars.ac.id/artikel/2015-03-23- 
$99-$

1\%20JURNAL\%20GEMA\%20IFTITAH.pdf.

18. Asmara R, Hananti N, Purwaningsih IA. Pengaruh faktor ekonomi dan non-ekonomi terhadap diversifikasi pangan berdasarkan PPH: studi kasus di dusun Klagen, desa Kepuh Kembeng, Kecamatan Peterongan, Kabupaten Jombang. Agrise. 2009; 9(1):19. www.agrise.ub.ac.id. Diunduh tanggal 8 September 2016.

19. Ariani M. Analisis konsumsi pangan tingkat masyarakat mendukung pencapaian diversifikasi pangan. Gizi Indon. 2010; 33(1): 20-28. Ejournal.persagi.org.
20. Hamid U, Setiawan B, Suhartini S. Analisis pola konsumsi pangan rumah tangga: studi kasus di Kecamatan Tarakan Barat Kota Tarakan Propinsi Kalimantan Timur. Agrise. 2013; 13(3): 176. agrise.ub.ac.id.

21. Ismail NM. Gerakan Diversifikasi Pangan: Sebuah Evaluasi. Makalah disampaikan pada Workshop "Bersama Membangun Gizi Menuju Bangsa Sehat Berprestasi". Jakarta, 24 Februari 2015.

22. Tempo.co.metro. 2013. Nurmahmudi Ismail bikin batik ODNR. http://metro.tempo.co, Rabu 2 Oktober 2013. Diunduh tanggal 4 September 2016. 